\title{
Fuzzy Sugeno Untuk Menentukan Penilaian Kompetensi Karyawan PT. Schneider Batam
}

\author{
Pastima Simanjuntak ${ }^{1}$, Cosmas Eko Suharyanto ${ }^{2}$, Riri Khairiyah ${ }^{3}$ \\ * Corresponding author : p.lastria@gmail.com \\ 1,2,3 Fakultas Teknik Universitas Putera Batam \\ Jalan R. Soeprapto, Muka Kuning, Batam
}

Abstract-- In a work process in companies, employees spearhead the first in the production process. Competencies possessed by each employee will show the quality of employees in performing their duties. It aims to look at the extent of competences of the employees, improvement and supervision competencies for employees. So that corporate leaders can make decisions choosing the best of the best employees. Assessment was conducted on the motive, knowledge, skills, and self-concept. So far there is no system that can be used to determine how big the competency of employees. therefore, this study used a system of decision-making using fuzzy logic with Sugeno method zero-orde for assessing the competence of employees in PT Schneider Batam. For the processing of data using MATLAB. The first step completion of competence assessment of employees using Sugeno that determines the input variables and output variables are set firmly, the second step is to convert the input variable into fuzzy sets with the process of fuzzification.

Keywords: Competency, fuzzy logic, Sugeno method, MATLAB.

Abstrak-- Dalam sebuah proses kerja disuatu perusahaan, karyawan menjadi ujung tombak pertama dalam proses produksi. Kompetensi yang dimiliki oleh setiap karyawan akan menunjukkan kualitas karyawan dalam menjalankan tugasnya. Hal ini bertujuan untuk melihat sejauh mana kompetensi yang dimiliki karyawan, peningkatan dan pengawasan kompetensi bagi karyawan. Sehingga pemimpin perusahaan dapat mengambil keputusan memilih karyawan terbaik dari yang terbaik. Penilaian yang dilakukan meliputi motif, pengetahuan, keterampilan, dan konsep diri. Sejauh ini belum ada sistem yang yang bisa digunakan untuk menentukan seberapa besar kompetensi yang dimiliki oleh karyawan . Oleh karena itu penelitian ini menggunakan sistem pengambilan keputusan dengan menggunakan logika fuzzy dengan metode Sugeno orde nol untuk melakukan penilaian terhadap kompetensi karyawan di PT Schneider Batam. Untuk pengolahan data menggunakan MATLAB. Langkah pertama penyelesaian penilaian kompetensi karyawan dengan menggunakan metode Sugeno yaitu menentukan variabel input dan variabel output yang merupakan himpunan tegas, langkah kedua yaitu mengubah variabel input menjadi himpunan fuzzy dengan proses fuzzifikasi.

Kata Kunci: Penilaian Kompetensi, Logika fuzzy, metode Sugeno, MATLAB.

\section{PENDAHULUAN}

Batam terkenal dengan kota industri. Batam menjadi salah satu tujuan investasi yang menarik karena ketersediaan lahan industri, tingkat pendapatan yang bersaing dan tenaga kerja terampil yang sangat mencukupi. Batam memiliki banyak sumberdaya dan peluang investasi di 
berbagai bidang seperti bidang industri. Dan saat ini Kota Batam telah menjadi daerah industri terkemuka di tanah air. Salah satu sektor perindustrian di Kota Batam seperti PT Schneider, kehadiran teknologi informasi menjadi salah satu aspek penting, karena kebutuhan akan informasi informasi terbaru dan terlengkap dalam suatu produk maupun jasa untuk costumers sangatlah diperlukan. Oleh karena itu diharapkan kemajuan teknologi dapat mengiringi kemajuan di sektor perindustrian sehingga jumlah penjualan dapat semakin meningkat.

Perkembangan teknologi saat ini tidak dapat dihentikan karena ini sangat berkaitan dengan sifat manusia yang selalu memiliki rasa ingin tahu yang besar. Begitu juga dengan kualitas sumber daya manusia yang diperlukan untuk meningkatkan produktivitas kinerja suatu instansi. Oleh karena itu diperlukan sumber daya manusia yang mempunyai kompetensi tinggi, karena keahlian atau kompetensi akan dapat mendukung peningkatan prestasi kerja karyawan. Penilaian kompetensi karyawan yang dilakukan di PT Schneider digunakan untuk proses meningkatkan kompetensi karyawan dan prestasi kerja. Penilaian kompetensi berarti bawahan mendapat perhatian dari atasannya sehingga mendorong karyawan semangat untuk bekerja, asalkan proses penilaian jujur dan objektif serta ada tindak lanjutnya. ${ }^{[1]}$

Untuk penilaian kompetensi karyawan tersebut diperlukan sebuah perangkat lunak yang dibangun untuk mengatasi permasalahan tersebut. Salah satu solusinya adalah dengan menggunakan sistem pengambilan keputusan. PT Schneider biasanya melakukan penilaian dengan cara manual atau dengan pengetahuan seorang atasan dari bawahan yang bersangkutan. Penilaian dengan cara manual seperti ini terkadang menimbulakan masalah karena kurang objektif, serta belum adanya suatu sistem untuk menentukan kompetensi karyawan. Banyaknya kriteria yang digunakan dalam proses penilaian kompetensi karyawan menyulitkan pihak manajemen untuk memberi bobot setiap kriteria. Untuk mengatasi masalah tersebut peneliti bertujuan menyelesaikan masalah tersebut dengan membuat sebuah sistem keputusan menggunakan logika fuzzy sugeno.

Menurut Wibowo (2014: 271) kompetensi adalah suatu kemampuan untuk melaksanakan atau melakukan suatu pekerjaan atau tugas yang dilandasi atas keterampilan dan pengetahuan serta didukung oleh sikap kerja yang dituntut oleh pekerjaan tersebut. Dengan demikian, kompetensi menunjukkan keterampilan atau pengetahuan yang dicirikan oleh profesionalisme dalam suatu bidang tertentu sebagai sesuatu yang terpenting, sebagai unggulan bidang tersebut. ${ }^{[11]}$ Spencer dan Spencer (1993: 9) yang dikutip oleh Wibowo, menyatakan bahwa indikator kompetensi merupakan landasan dasar karakteristik orang dan mengindikasikan cara berprilaku atau berpikir, menyamakan situasi, dan mendukung untuk periode waktu cukup lama. Terdapat 5 tipe karakteristik kompetensi, yaitu sebagai berikut:

a. Motif adalah sesuatu yang secara konsisten dipikirkan atau diinginkan orang yang menyebabkan tindakan.

b. Sifat adalah karakteristik fisik dan respon yang konsisten terhadap situasi atau informasi.

c. Konsep diri adalah sikap, nilai-nilai, atau citra diri seseorang. Percaya diri merupakan keyakinan orang bahwa mereka dapat efektif dalam hampir setiap situasi.

d. Pengetahuan adalah informasi yang dimiliki orang dalam bidang spesifik.

e. Keterampilan adalah kemampuan mengerjakan tugas fisik atau mental tertentu.

Pada penelitian ini karakteristik yang digunakan oleh PT Schneider Batam dalam penilaian Kompetensi karyawan hanya 4 karakterisitk saja. Diantaranya yaitu : Motif, konsep diri, pengetahuan, dan keterampilan.

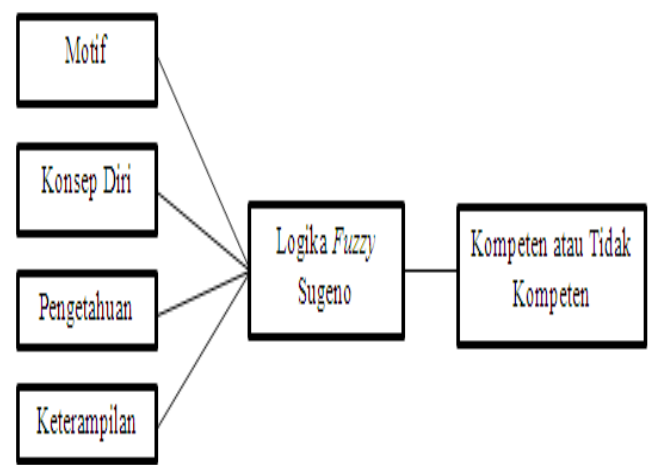

Gambar 1. Kerangka Pemikiran 


\section{METODE PENELITIAN}

Desain dari penelitian adalah semua proses yang diperlukan dalam perencanaan dan pelaksanaan penelitian. Dalam pengertian yang lebih sempit, desain penelitian hanya mengenai pengumpulan dan analisis data saja. Dalam merencanakan penelitian, desain dimulai dengan mengadakan penyelidikan dan evaluasi terhadap penelitian yang sudah dikerjakan dan diketahui, dalam memecahkan masalah. Dari penyelidikan ini, akan terjawab bagaimana hipotesis dirumuskan dan diuji dengan data yang diperoleh untuk memecahkan suatu masalah. Dari sini pula dapat dicari beberapa petunjuk tentang desain yang akan dibuat untuk penelitian yang akan dikembangkan.

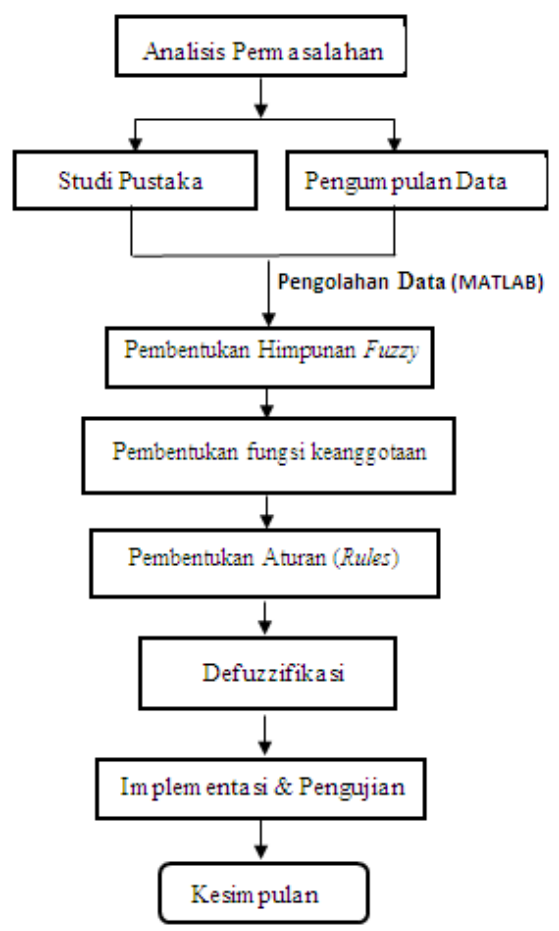

Gambar 2. Desain Penelitian

Menurut Sambas dan Maman (2007: 52) metode analisis data dapat diartikan sebagai cara melaksanakan analisis terhadap data, dengan tujuan mengolah data tersebut menjadi informasi, sehingga karakteristik atau sifat-sifat datanya dapat dengan mudah dipahami dan bermanfaat untuk menjawab masalah-masalah yang berkaitan dengan kegiatan deskripsi data maupun untuk membuat induksi atau menarik kesimpulan tentang karakteristik populasi berdasarkan data yang diperoleh dari sampel.

Metode penerapan yang digunakan dalam penelitian logika fuzzy ini menggunakan metode sugeno. Logika fuzzy dengan metode sugeno sebenarnya hampir sama dengan penalaran metode mamdani, hanya saja output (konsekuen) sistem tidak berupa himpunan fuzzy, melainkan berupa konstanta atau persamaan linear.

Langkah - langkah penerapan metode sugeno menggunakan tahapan berikut:

1. Fuzzifikasi

Pada tahapan ini variabel input (crisp) dari sistem fuzzy ditransfer ke dalam himpunan fuzzy untuk dapat digunakan dalam perhitungan nilai kebenaran dari premis pada setiap aturan dalam basis pengetahuan. Dengan demikian tahap ini mengambil nilai-nilai crisp dan menentukan derajat di mana nilai-nilai tersebut menjadi anggota dari setiap himpunan fuzzy yang sesuai.

2. Aplikasi Fungsi Implikasi

Tiap-tiap aturan (proposisi) pada basis pengetahuan fuzzy akan berhubungan dengan suatu relasi fuzzy. Bentuk umum dari aturan yang digunakan dalam fungsi implikasi adalah sebagai berikut: IF $\mathrm{x}$ is A THEN y is B Dengan $\mathrm{x}$ dan $\mathrm{y}$ adalah skalar, dan $\mathrm{A}$ dan $\mathrm{B}$ adalah himpunan fuzzy. Proposisi yang mengikuti IF disebut sebagai anteseden sedangkan proposisi yang mengikuti THEN disebut konsekuen. Proposisi ini dapat diperluas dengan menggunakan operator fuzzy seperti, $\operatorname{IF}(\mathrm{x} 1$ is $\mathrm{A} 1)$ o $(\mathrm{x} 2$ is $\mathrm{A} 2)$ o $(\mathrm{x} 3$ is $\mathrm{A} 3)$ o...o ( $\mathrm{xN}$ is $\mathrm{AN})$ THEN y is $\mathrm{B}$ dengan o adalah operator (misal: OR atau AND). Secara umum fungsi implikasi yang dapat digunakan yaitu sebagai berikut:

a. .Min (minimum) Fungsi ini akan memotong output himpunan fuzzy.

b. Dot (product) Fungsi ini akan menskala output himpunan fuzzy. Pada metode Sugeno ini, fungsi implikasi yang digunakan adalah fungsi min.

3. Penegasan (defuzzifikasi)

Input dari proses defuzzifikasi adalah suatu himpunan fuzzy yang diperoleh dari komposisi aturan-aturan fuzzy, sedangkan output yang dihasilkan merupakan suatu bilangan pada domain himpunan fuzzy tersebut. Sehingga jika diberikan suatu himpunan fuzzy dalam range 
tertentu, maka harus dapat diambil suatu nilai crisp tertentu sebagai output.

\section{HASIL DAN PEMBAHASAN}

Penelitian ini bertujuan untuk mengimplementasikan sistem fuzzy sugeno untuk kompetensi karyawan di PT Schneider Batam.

A.Pembentukan Himpunan Fuzzy (Fuzzifikasi). Untuk melakukan simulasi semua himpunan fuzzy maupun blok aturan harus dimasukkan kedalam sistem. Secara garis besar sistem ini akan memiliki 4 input (motif, konsep diri, pengetahuan, dan keterampilan) dan output (kompeten/ tidak kompeten) seperti pada gambar berikut :

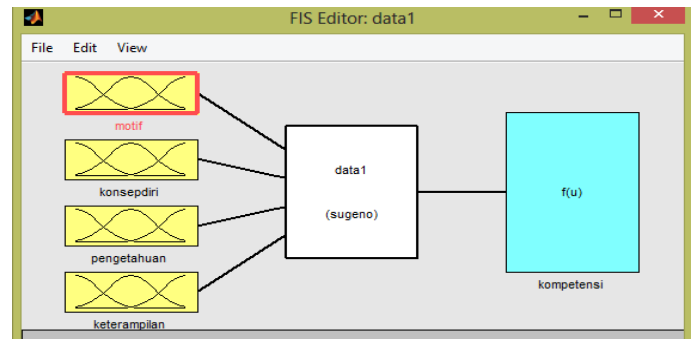

Gambar 3. Rancangan Sistem

Himpunan fuzzy yang dibuat untuk tiap-tiap variabel input dan output adalah sebagai berikut:

1. Variabel Input

a. Motif

Himpunan universal untuk Motif adalah nilai minimum 1 dan nilai maksimum 5 Maka himpunan universal untuk motif yaitu U1 = [1 5].

b. Konsep Diri

Himpunan universal untuk konsep diri adalah nilai minimum 1 dan nilai maksimum 5 Maka himpunan universal untuk Konsep diri yaitu $\mathrm{U} 2=\left[\begin{array}{ll}1 & 5\end{array}\right]$.

c. Pengetahuan

Himpunan universal untuk pengetahuan adalah nilai minimum 1 dan nilai maksimum 5 Maka himpunan universal untuk Pengetahuan yaitu U3 = [1 5].

d. Keterampilan

Himpunan universal untuk keterampilan adalah nilai minimum 1 dan nilai maksimum 5 Maka himpunan universal untuk Keterampilan yaitu U4 $=$ [1 5].

2. Variabel output

Himpunan universal untuk variabel output adalah nilai 0,5 sampai 1 maka dinyatakan 100 Fuzzy Sugeno Untuk...
Kompeten dan nilai < 0,5 Maka dinyatakan Tidak Kompeten universal untuk Output yaitu Upenilaian $=\left[\begin{array}{ll}0 & 1\end{array}\right]$.

Tabel 1. Himpunan Fuzzy

\begin{tabular}{|c|c|c|}
\hline Fungsi & $\begin{array}{l}\text { Nama } \\
\text { Variabel }\end{array}$ & $\begin{array}{l}\text { Himpunan } \\
\text { Fuzzy }\end{array}$ \\
\hline \multirow{12}{*}{ Input } & \multirow{3}{*}{ Motif } & Kurang \\
\hline & & Cukup \\
\hline & & Baik \\
\hline & \multirow{3}{*}{ Konsep Diri } & Kurang \\
\hline & & Cukup \\
\hline & & Baik \\
\hline & \multirow{3}{*}{ Pengetahuan } & Kurang \\
\hline & & Cukup \\
\hline & & Baik \\
\hline & \multirow{3}{*}{ Keterampilan } & Kurang \\
\hline & & Cukup \\
\hline & & Baik \\
\hline \multirow{2}{*}{ Output } & \multirow{2}{*}{ Penilaian } & Kompeten \\
\hline & & $\begin{array}{l}\text { Tidak } \\
\text { Kompeten }\end{array}$ \\
\hline
\end{tabular}

Tebel 2. Semesta Pembicaraan

\begin{tabular}{|l|l|c|l|}
\hline \multirow{4}{*}{ Fungsi } & \multicolumn{1}{|c|}{ Variabel } & $\begin{array}{c}\text { Semesta } \\
\text { Pembicaraan }\end{array}$ & \multicolumn{1}{|c|}{ Keterangan } \\
\hline Variabel & Motif & {$[1-5]$} & Nilai Motif \\
\cline { 2 - 4 } & Konsep diri & {$[1-5]$} & Nilai Konsep diri \\
\cline { 2 - 4 } & Pengetahuan & {$[1-5]$} & Nilai Pengetahuan \\
\cline { 2 - 4 } & Keterampilan & {$[1-5]$} & Nilai Keterampilan \\
\hline Output & Kompeten & {$[0-1]$} & Karyawan Berkompeten \\
\cline { 2 - 4 } & Tidak Kompeten & {$[0-1]$} & Karyawan Tidak Kompeten \\
\hline
\end{tabular}

Tabel 3. Domain

\begin{tabular}{|c|c|c|c|}
\hline Fungsi & Variabel & Nama Himpunan Fuzzy & Domain \\
\hline \multirow{4}{*}{ Motif } & Kurang & {$[13]$} \\
\cline { 3 - 4 } & & Cukup & {$[24]$} \\
\cline { 3 - 4 } & \multirow{4}{*}{ Konsep diri } & Baik & {$[35]$} \\
\cline { 3 - 4 } & & Kurang & {$[13]$} \\
\cline { 3 - 4 } & & Cukup & {$[24]$} \\
\cline { 3 - 4 } & \multirow{4}{*}{ Pengetahuan } & Baik & {$[35]$} \\
\cline { 3 - 4 } & & Kurang & {$[13]$} \\
\cline { 3 - 4 } & & Cukup & {$[24]$} \\
\cline { 3 - 4 } & & Baik & {$[35]$} \\
\cline { 3 - 4 } & \multirow{4}{*}{ Keterampilan } & Kurang & {$[13]$} \\
\cline { 3 - 4 } & & Cukup & {$[24]$} \\
\cline { 3 - 4 } & & Baik & {$[35]$} \\
\hline
\end{tabular}




\section{B. Fungsi Keanggotaan}

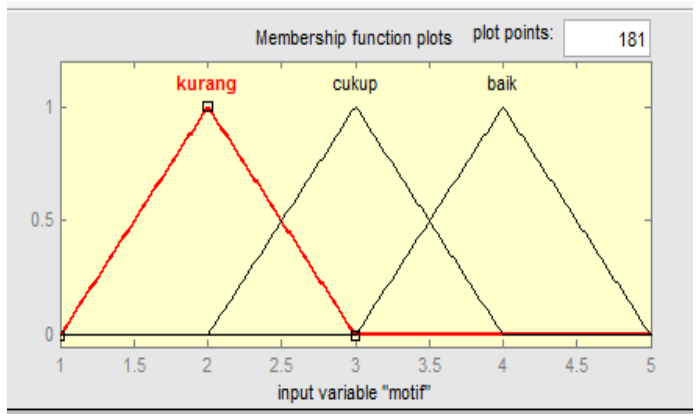

Gambar 4. Fungsi keanggotaan variabel motif

$$
\begin{aligned}
& \mu_{\text {Baik }}=\left\{\begin{array}{lc}
0 & ; \mathrm{x} \leq 3 \text { atau } \mathrm{x} \geq 5 \\
\frac{(\mathrm{x}-3)}{(4-3)} ; & 3 \leq \mathrm{x} \leq 4 \\
\frac{(5-\mathrm{x})}{(5-4)} ; & 4 \leq \mathrm{x} \leq 5
\end{array}\right. \\
& \mu_{\text {Cukup }}=\left\{\begin{array}{cc}
0 & ; x \leq 2 \text { atau } x \geq 4 \\
\frac{(x-2)}{(3-2)} ; & 2 \leq x \leq 3 \\
\frac{(3-x)}{(4-3)} ; & 3 \leq x \leq 4
\end{array}\right. \\
& \mu_{\text {kurang }}=\left\{\begin{array}{lcc}
0 & ; & \mathrm{x} \leq 1 \text { atau } \mathrm{x} \geq 3 \\
\frac{(\mathrm{x}-1)}{(2-1)} ; & 1 \leq \mathrm{x} \leq 2 \\
\frac{(2-\mathrm{x})}{(3-2)} ; & 2 \leq \mathrm{x} \leq 3
\end{array}\right.
\end{aligned}
$$

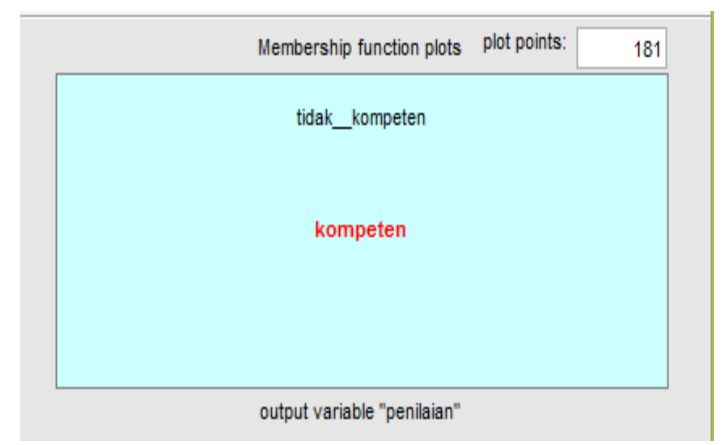

Gambar 5. Fungsi keanggotaan variabel output penilaian

Penyelesaian masalah untuk menentukan penilaian kompetensi karyawan di PT Schneider Batam dengan logika fuzzy menggunakan metode Sugeno, adalah sebagai berikut:

Menentukan variabel yang terkait dalam proses yang akan ditentukan dan fungsi fuzzifikasi yang sesuai dari sampel untuk menentukan penilaian kompetensi karyawan yang kompeten atau tidak kompeten, dan ada 5 sampel yang akan di uji pada penelitian ini, ada 4 variabel yang akan dimodelkan yaitu:

Tabel 4. Data Penilaian kompetensi karyawan dari SPV Production

\begin{tabular}{|l|c|c|c|c|}
\hline \multirow{2}{*}{ Data Karyawan } & \multicolumn{4}{|c|}{ Variabel } \\
\cline { 2 - 5 } & Motif & $\begin{array}{l}\text { Konsep } \\
\text { diri }\end{array}$ & Pengetahuan & Keterampilan \\
\hline $\begin{array}{l}\text { ESLINA } \\
\text { SIMAMORA }\end{array}$ & 3,5 & 3,5 & 3,5 & 3,5 \\
\hline NUR FITRIANI & 3 & 2,5 & 3 & 3,5 \\
\hline ROLIYANI & 3 & 2,5 & 4 & 3,5 \\
\hline HARJONO & 3,5 & 3,5 & 4 & 3,5 \\
\hline KASMAWATI & 3,5 & 3,5 & 4 & 4 \\
\hline
\end{tabular}

Sumber: PT Schneider Batam

Nilai derajat keanggotaan terkecil digunakan sebagai representasi aturan dalam himpunan fuzzy. Proses untuk mendapatkan aturan fuzzy yang akan dihitung menggunakan MATLAB. Namun akan diberi contoh manual membuat aturan dengan data pertama yaitu sampel material Pertama. Pembuatan aturan ini diperoleh dengan 4 variabel input.

Menentukan derajat keanggotaan dalam himpunan fuzzy input pada karyawan kedua.

Tabel 5. Data pada karyawan 2

\begin{tabular}{|l|c|}
\hline \multicolumn{1}{|c|}{ Variabel } & Karyawan 2 \\
\hline Motif & 3 \\
\hline Konsep diri & 2,5 \\
\hline Pengetahuan & 3 \\
\hline Keterampilan & 3,5 \\
\hline
\end{tabular}

Nilai derajat keanggotaan dari penilaian karyawan kedua adalah:

\section{Motif}

Motif dari penilaian karyawan pertama adalah 3,5. Himpunan fuzzy pada input Motif dibagi menjadi 3 himpunan fuzzy yaitu Baik, Cukup dan Kurang dengan rentang nilai [1 - 5].

$\mu_{\text {Baik }}(3)=\frac{(3-3)}{(4-3)}$, Sehingga derajat keanggotaan Baik $=0$.

$\mu_{\text {Cukup }}(3)=\frac{(4-3)}{(4-3)}$, Sehingga derajat keanggotaan Cukup $=1$. 
$\mu_{\text {Kurang }}(3)=0$, Sehingga derajat keanggotaan Kurang $=0$.

\section{Konsep diri}

Konsep diri dari penilaian karyawan pertama adalah 4. Himpunan fuzzy pada input Konsep diri dibagi menjadi 3 himpunan fuzzy yaitu Baik, Cukup dan dan Kurang dengan rentang nilai [1 5].

$\mu_{\text {Baik }}(2,5)=\frac{(2,5-3)}{(4-3)}, \quad$ Sehingga derajat keanggotaan Baik $=0$.

$\mu_{\text {Cukup }}(2,5)=\frac{(2,5-2)}{(3-2)}, \quad$ Sehingga derajat keanggotaan Cukup $=0,5$.

$\mu_{\text {Kurang }}(2,5)=\frac{(2-2,5)}{(3-2)}, \quad$ Sehingga derajat keanggotaan Cukup $=0$.

3. Pengetahuan

Pengetahuan dari penilaian dari karyawan pertama adalah 3,5. Himpunan fuzzy pada input pengetahuan di bagi menjadi 3 himpunan fuzzy yaitu Baik, Cukup dan Kurang dengan rentang nilai [1 - 5].

$\mu_{\text {Baik }}(3)=\frac{(3-3)}{(4-3)}$, Sehingga derajat keanggotaan Baik $=0$.

$\mu_{\text {Cukup }}(3)=\frac{(4-3)}{(4-3)}$, Sehingga derajat keanggotaan Cukup $=1$.

$\mu_{\text {Kurang }}(3)=0$, Sehingga derajat keanggotaan Kurang $=0$.

4. Keterampilan

Keterampilan dari penilaian karyawan pertama adalah 3,5. Himpunan fuzzy pada input keterampilan di bagi menjadi 3 himpunan fuzzy yaitu Baik, Cukup dan Kurang dengan rentang nilai [1 - 5].

$\mu_{\text {Baik }}(3,5)=\frac{(3,5-3)}{(4-3)}, \quad$ Sehingga derajat keanggotaan Baik $=0,5$.

$\mu_{\text {Cukup }}(3,5)=\frac{(4-3,5)}{(4-3)}, \quad$ Sehingga derajat keanggotaan Cukup $=0,5$.

$\mu_{\text {Kurang }}(3,5)=0$, Sehingga derajat keanggotaan Kurang $=0$.

$\mu_{\text {Motif Baik }}(3)=0$

$\mu_{\text {Motif Cukup }}(3)=1$

$\mu_{\text {Motif Kurang }}(3)=0$

$\mu_{\text {Konsep_diri Baik }}(2,5)=0$

$\mu_{\text {Konsep_diri Cukup }}(2,5)=0,5$

$\mu_{\text {Konsep_diri Kurang }}(2,5)=0,5$

$\mu_{\text {Pengetahuan Baik }}(3)=0$

$\mu_{\text {Pengetahuan Cukup }(3)=1}$

$\mu_{\text {Pengetahuan Kurang }}(3)=0$

$\mu_{\text {Keterampilan Baik }}(3,5)=0,5$ $\mu_{\text {Keterampilan Cukup }}(3,5)=0,5$

$\mu_{\text {Keterampilan Kurang }}(3,5)=0$

Kemudian mencari $\alpha$-predikat untuk aturan yang memiliki nilai derajat keanggotaan selain nol, dikarenakan pencarian defuzzifikasi hanya mengambil nilai $\alpha$-predikat selain nol, aturannya sebagai berikut:

[R40] If Motif is Cukup And Konsep_diri is Cukup And Pengetahuan is Cukup And Keterampilan is Baik Then Penilaian is Kompeten $=[1]$.

$\alpha$-predikat $40=\min \left(\mu_{\text {Motif }} \quad\right.$ Cukup $(3) ; \mu_{\text {konsep_diri }}$ Cukup $\left.(2,5) ; \mu_{\text {Pengetahuan Cukup }}(3) ; \mu_{\text {Keterampilan Baik }}(3,5)\right)$

$$
\begin{array}{rlrl} 
& = & & \min (1 ; 0,5 ; 1 ; 0,5) \\
& = & 0,5 \\
\mathrm{Z}_{40} & = & 1
\end{array}
$$

Selanjutnya Perbandingan dengan menggunakan Matlab, dengan memasukan nilai input karyawan 2. Seperti gambar berikut:

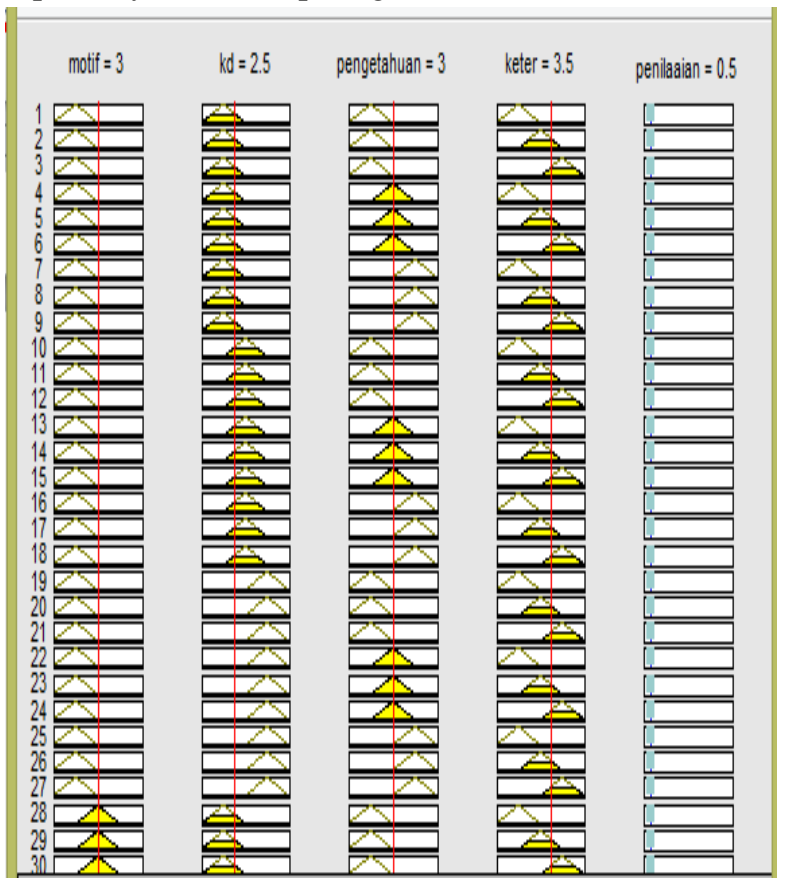

Gambar 6. Defuzzifikasi Matlab Karyawan 2

Tabel 6. Review Pengujian

\begin{tabular}{|l|c|c|c|}
\hline \multicolumn{1}{|c|}{ Karyawan } & $\begin{array}{c}\text { Hasil } \\
\text { Defuzzifikasi }\end{array}$ & Hasil Matlab & Keterangan \\
\hline ESLINA SIMAMORA & 1 & 1 & Benar \\
\hline NUR FITRIANI & 1 & 1 & Benar \\
\hline ROLIYANI & 1 & 1 & Benar \\
\hline HARJONO & 1 & 1 & Benar \\
\hline KASMAWATI & 1 & 1 & Benar \\
\hline
\end{tabular}

102| Fuzzy Sugeno Untuk... 
Pembuatan model fuzzy untuk penilaian kompetensi karyawan belum dikatakan baik sehingga perlu dilakukan pengujian terhadap karyawan sebanyak 5 sampel tentang keakuratan dan error dari pengujian. Pengujian ini menggunakan tingkat keakuratan.

Tingkat Keakuratan

$$
=\frac{\text { Jumlah Data Benar }}{\text { Jumlah Data Keseluruhan }} \times 100 \%
$$

Berdasarkan tabel diatas didapat sebagai berikut:

$$
\begin{array}{cc}
\text { Jumlah data benar } & : 5 \\
\text { Jumlah data seluruhnya } & : 5 \\
\text { Tingkat Keakuratan }=\frac{5}{5} \times 100 \% & \\
\text { Tingkat Keakuratan }=100 \%
\end{array}
$$

Sehingga tingkat akuratan model fuzzy dengan fungsi keanggotaan segitiga yang digunakan untuk mengklasifikasikan penilaian kompetensi karyawan pada data sebesar $100 \%$ tanpa ada Error. Dengan demikian logika fuzzy dengan metode Sugeno bermanfaat dalam menentukan penilaian kompetensi karyawan, dan dapat membantu atasan dalam mengambil keputusan dan tindak lanjut dari karyawan yang berkompeten atau tidak kompeten.

\section{KESIMPULAN}

Berdasarkan hasil pengujian yang telah dilakukan, serta uraian-uraian yang telah dikemukakan, maka dapat diambil kesimpulan bahwa permasalahan tersebut dapat diselesaikan dengan menggunakan logika fuzzy sebagai alat bantu dalam menentukan penilaian kompetensi karyawan pada PT Schneider Batam. Diperoleh hasil penilaian 100 persen dengan menghasilkan penilaian yang kompeten dari lima sampel karyawan yang telah diuji menggunakan metode Sugeno. Logika fuzzy dengan metode Sugeno bermanfaat dalam menentukan penilaian kompetensi karyawan serta penilaian kompetensi karyawan dengan logika fuzzy Sugeno efektif dan efisien untuk diterapkan dalam perusahaan.

\section{DAFTAR PUSTAKA}

[1]Jimmy, Chr. 2015. A to Z Human Capital Manajemen Sumber Daya Manusia. Grasindo. Jakarta.

[2]Kusumadewi, Sri dan Purnomo, Hari. 2010. Aplikasi Logika Fuzzy Untuk Pendukung Keputusan. Graha Ilmu. Yogyakarta.
[3]Meimaharani, Rizkysari. 2014. Analisis Sistem Inference Fuzzy Sugeno Dalam Menentukan Harga Penjualan Tanah Untuk Pembangunan Minimarket. Jurnal SIMETRIS, Vol 5 No 1. 2252-4983.

[4]Mufidah, Silvya L. Mandey, Lisbeth Mananeke. 2014. Analisis Tingkat Pendidikan, Kompetensi dan Kompensasi Terhadap Kinerja Karyawan Pada PT.Asuransi Jasaraharja Putera Manado. Volume 2 no. 2. 2303-1174.

[5] Naba, Agus. 2009. Belajar Cepat Fuzzy Logic Menggunakan Matlab. Andi. Yogyakarta.

[6]Sifaunajah, Agus. 2015. Penggunaan fuzzy Sugeno Pada Rancang Bangun Sistem Pembangun Keputusan. Volume 8 no.1. 1979-7141.

[7]Sudaryono. 2015. Metodologi Riset di Bidang TI. Andi. Yogyakarta.

[8]Sugiyono. 2014. Metode Penelitian Kuantitatif, Kualitatif dan R \& D. Alfabeta. Bandung.

[9]Taufiq, Ghofar. 2014. Logika Fuzzy Tahani Untuk Mendukung Keputusan Perekrutan Karyawan Tetap. Prosiding Seminar Nasional Aplikasi Sains \& Teknologi. 1979-911X.

[10]Tito Pinandita, Ahmad, dan Hindayati Mustafidah. 2014. Sistem Penentuan Tingkat Kompetensi Pendidik Menggunakan Fuzzy Inference System Berbasis Web. Jurnal Generic, Vol. 9, No. 1. 1907-4093.

[11]Wibowo. 2014. Manajemen Kinerja. PT Raja Grafindo Persada. Jakarta. 